\title{
The Effects of Green Spaces (Palme Trees) on the Microclimate in Arid Zones, Case Study: Ghardaia , Algeria
}

\author{
Hamida bencheikh ${ }^{1, *}$, Ameur Rchid ${ }^{2}$ \\ ${ }^{1}$ Genie civil laboratory Amar Telidji University Laghouat Algeria \\ ${ }^{2}$ Depatement of architecture Amar Telidji University Laghouat Algeria
}

\begin{abstract}
The mic roclimate and air quality in urban spaces are of a great interest for the well-being of citizens. Mitigating urban heat island is a major concern for human health by improving comfort especially in desert regions. While the thermal comfort is relatively easy to obtain in indoor spaces, it is more difficult to provide in outdoor ones. It is often sought by passive means. Vegetation could play an important role in ameliorating urban microclimates. It should be used judiciously in urban planning and designing outdoor spaces. The objective of this work is to explore the influence of green cover during summer on microclimate in the region of Ben-Isguen, a city of a hot-arid climate in the M'zab valley, Ghardaïa (Algeria). Many studies have proved that vegetation can produce a cooling effect of 2 to $3^{\circ} \mathrm{C}$ on average. Gardens and urban parks in particular, in and around cities contribute to alleviating heat stress by creating the so-called "oasis effect" through public spaces. They improve thermal comfort and reduce cooling energy consumption. The microclimate of different locations, in both green and built-up areas (old town, palm grove, etc.) was characterized with the help of field measurements carried out during summer days. The results confirmed the presence of an important cooling effect of vegetation (PCI). It was shown that it is essentially a nocturnal phenomenon by displaying a maximum value of $10{ }^{\circ} \mathrm{C}$. This result is very important regarding the results of similar studies. The research demonstrated that the oasis effect is best developed around dawn in calm and clear sky conditions. Maximum daytime cooling effect of the green cover was $4.5^{\circ} \mathrm{C}$ in reference to old town. Nevertheless this effect showed fluctuation so that it displayed negative values by moments. The cooling effect of the palm grove is due to shade foliage, evapotranspiration, low heat capacity of vegetation and high aerodynamic roughness. In fact the oasis acts as a "heat sink". The old town of Ben-Isguen presented a diurnal heat island and a nocturnal cool island with maximum intensity of $3.5^{\circ} \mathrm{C}$ and $4^{\circ} \mathrm{C}$ respectively. The investigation of the oasis mic roclimate revealed that densely vegetated areas display higher cooling effect. The latter varied a mong different areas due to shade conditions, density of vegetation, sky view factor (SVF), soil characteristics and water surface availability.
\end{abstract}

Keywords Microclimate, Urban Space, Heat Island, Green Space, Arid Zone

\section{Introduction}

In the past, Mzab settlements (the ksurs and their cities gardens) were developed in response to both cultural and climatic needs of their inhabitants[1], the inhabitants of Mzab site use detached houses in Palme trees gardens for day living and the ksurs fornight living (due to security problems) and now they use garden houses for day and night living during summer period. Our study investigates the effects of vegetations on the outdoor temperatures in hot arid zones, and Ghardaia in the south of Algeria was taken as a case study.

* Corresponding author:

hamida.bencheikh@gm ail.com (Hamida bencheikh)

Published online at http://journal.sapub.org/arch

Copyright (C) 2012 Scientific \& Academic Publishing. All Rights Reserved
Vegetation cover has positive effects on the microclimate[2], it can lower the outdoor temperature[3-4-5]. Many studies on urban tree cover like green CTTC (cluster thermal time constant) model have indicated a very high correlation between daily outdoor temperature and consumption of space conditioning energy[6-7-8]. It is assumed that a tree has a projection area of shading and a reduction of sky view factor, in the air surrounding a tree always has a high humidity due to tree irrigations system. The surrounding space between detached houses in Palme trees are well protected from solar radiations and the surrounding air is usually saturated with humidity, which can affect directly the outdoor temperature. M. Santumouris [9] shows that trees with a crown of $8 \mathrm{~m}$ could reduce the peak cooling load by 2 to $10 \%$. A kbari[7], found that trees reduce the cooling load by $21-53 \%$ in California. This paper studies the effect of Palme trees on microclimate in arid 
zones, and Ghardaia in the south of Algeria $\left(32.3^{\circ} \mathrm{N}-3.49^{\circ} \mathrm{E}\right)$ was taken as a study case.

\section{Study Area}

Ghardaia is located in the south of Algeria, which is well known by its hot arid climate, its ksurs (dense old buildings), its river, and its detached hous es surrounded by Palme trees as shown in figure (1). The climate of Ghardaia is characterized by a very hot dry summer, the mean summer temperature in July is $36.8^{\circ} \mathrm{C}$ and the maximum absolute temperature is $46^{\circ} \mathrm{C}$.

The outdoor temperatures were recorded in four different sites in addition to the reference point; Figure (2) shows the different sites where field measurements were recorded.

The reference point is situated at the frontier of Palme trees site on the top of the local radio build ing and the first site, detached houses in Palme trees (Oasis) is situated at the bottom of the valley as shown in figure (3). The second site called Beni Ezgen ksur, the old part of the city (high density buildings and partially covered narrow streets as shown in figures $(4,5)$. The third site the new city extension called Tafilalt and the forth site is the new detached houses in open area without vegetations.

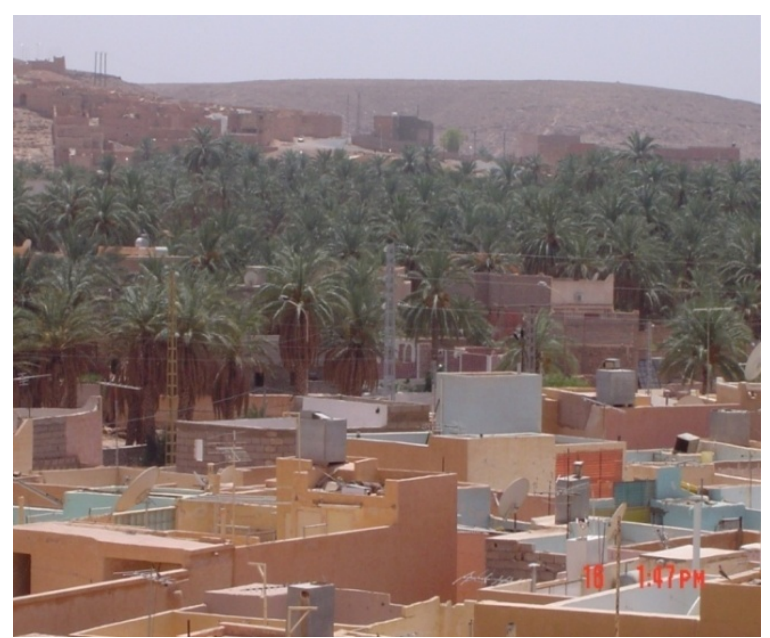

Figure 1. Houses surrounded by Palme trees

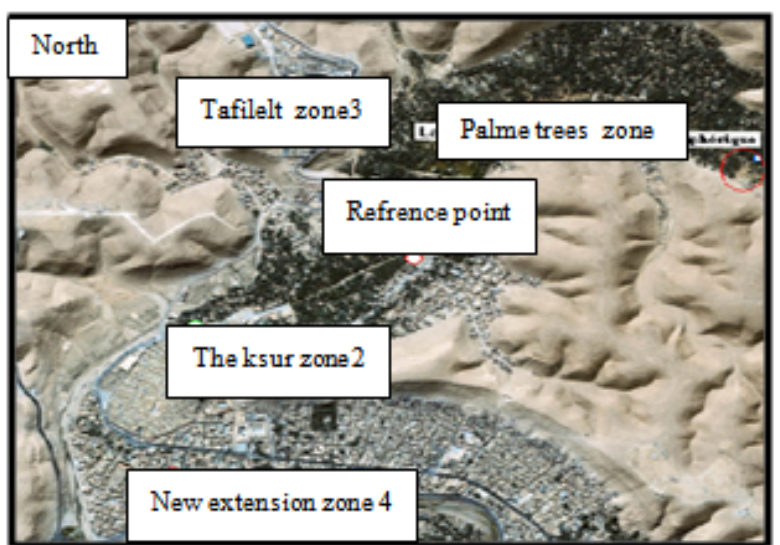

Figure 2. The different zones where field measurements were recorded

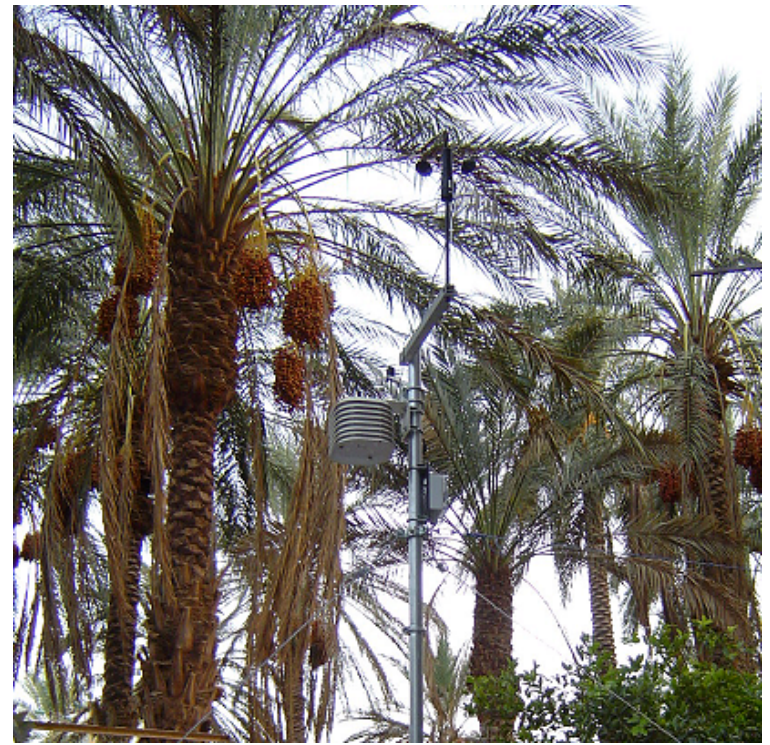

Figure 3. Weather station in Palme trees zone at low level

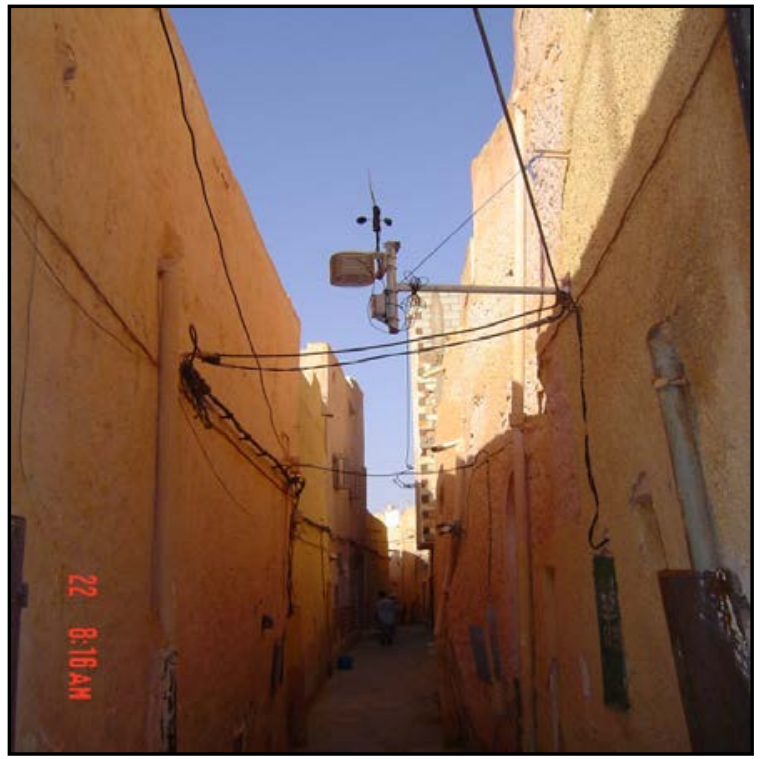

Figure 4. Weather station in the street of the old ksur Beni Ezgen

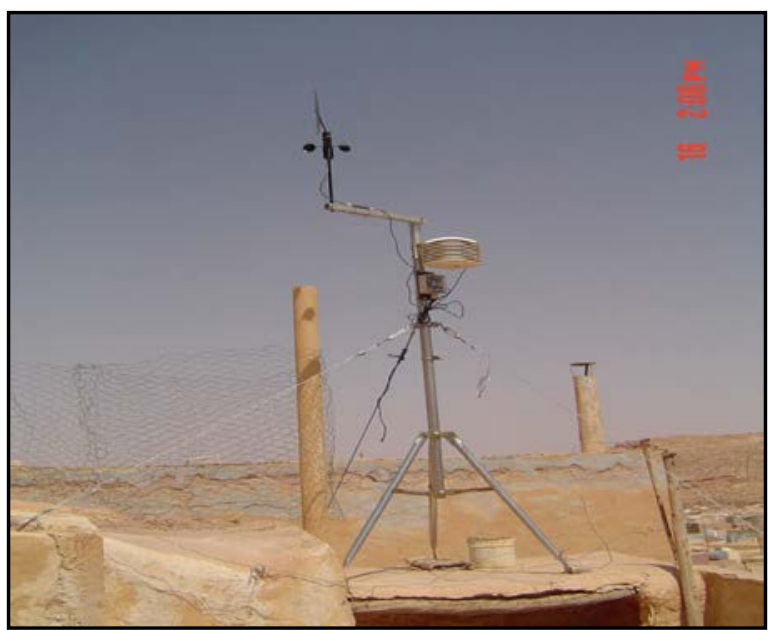

Figure 5. Weather station on the top of houses roof in the old ksur Beni Ezgen 


\section{Measurement Instrumentations}

Ten weather stations type HOBO where planted in five different points;

A reference weather station was planted on the top the local radio station in open area. In point one, the old ksur of Beni Ezgen, two weather stations were planted, one on the top of houses and the other one in $1.3 \mathrm{~m}$ wide street. In point two, Tafailelt, two weather stations were planted, one on the top of houses and the other in $6 \mathrm{~m} \mathrm{~W}$ ide Street. In point three, Palme trees houses, two weather stations were planted, one at human height above the soil, the second at canopies level on the top of houses. In Point four, new detached houses in open area, one weather station was planted on the top and the second in $4.7 \mathrm{~m}$ wide street. In point five, at the bottom of the valley one station was planted on the top of one level building. The streets weather stations were $4 \mathrm{~m}$ height from the ground for security raisons and the period of measurements was from the $16^{\text {th }}$ until $20^{\text {th }}$ of august. Figures (3 to 5) show the station at each site.

In addition to the weather stations, three same model testometers were used to measure the outdoor temperatures, relative humidity and wind speed in Palme trees zone. Two of them were placed in the Palme trees center (high density and continues canopies), the first one at $1.2 \mathrm{~m}$ of height and the second one at $5.5 \mathrm{~m}$ just below canopies, these measurement help in studying the temperature stratifications above the ground and at canopies level. The Palme trees were irrigated once a day at $18 \mathrm{~h} 30$. The third testometer was placed in the outer Palme trees site (less density and discontinues canopies). The testometers measurements were taken from $20^{\text {th }}$ until $22^{\text {nd }}$ August.

\section{Results and Discussion}

Ghardaia a hot arid city situated in the south of Algeria, the outdoor temperatures were recorded by fixed weather stations at two level points, street level and canopies level (roof of building and bottom of building) for the four mentioned sites and the reference weather station site. Figure (6) presents the outdoor temperature variation at building roof level in the four sites in comparison with the outdoor reference site. Figure (7) presents the outdoor temperature variation for the same sites at street level. Figures $(6,7)$ show that the high difference in outdoor temperatures between sites were recorded during night time at canopies level in palm trees site. At canopies of Palme trees the outdoor temperatures were higher by $0.5^{\circ} \mathrm{C}$ than the reference site in two times, early in morning and at midday due to solar radiation.
Under the canopies, in the Palm trees site and in the open site, the lower outdoor temperatures were recorded during night, which also cited by, Shashua-Bar and Hoffman[10], Bacci and al.[11] and S. Spronken and Oke[12]. The Oasis presents the lower outdoor temperature due to the intense evaporation and the low thermal capacity of the vegetations. The night outdoor temperatures recoded were lower by $4^{\circ} \mathrm{C}$ than the ones recorded in the open site, which was similar to the results in many bibliographical references such as; Correa \& al.[13] and Upmanis \& al.[14].

Figure (8) presents the heat-island and the cool -island (the negative values present the heat-island and the positive one present the cool-island) at the top of buildings and in the street of Beni Ezgen ksur compared to the reference point. The maximum cool-island was $4^{\circ} \mathrm{C}$ recorded at $4.10 \mathrm{Am}$ and the maximum heat-island was $3.5^{\circ} \mathrm{C}$ recorded at 13.00 pm.

Figure (9) presents the heat-island and the cool-island at the top and the bottom of buildings of Tafilelt ksur compared to the reference point. The maximum cool-island was $3.8^{\circ} \mathrm{C}$ recorded at $4.10 \mathrm{Am}$ and the maximum heat-island was $3^{\circ} \mathrm{C}$ recorded at $13.00 \mathrm{pm}$.

Figure (10) presents the heat-island and the cool-island at the top and the bottom of buildings of Palme trees site compared to reference point and the maximum cool-island was $10^{\circ} \mathrm{C}$ recorded twice and minimum value was $2^{\circ} \mathrm{C}$.

Figures $(11,12)$ present the cool-island in Palme trees site at the top and the bottom of buildings compared to the other three sites, Beni Ezgen ksur, Tafilelt ksur and open site hous es. The maximu m cool-island at the bottom of buildings level recorded during night time were $7.2^{\circ} \mathrm{C}, 9.2^{\circ} \mathrm{C}$ and 7.1 $1^{\circ} \mathrm{C}$ compared to Beni Ezgen ksur, Tafilelt ksur and open site houses respectively. The maximum cool-island at the top of buildings level were recorded during night time, $5.1^{\circ} \mathrm{C}$, $7.8^{\circ} \mathrm{C}$ and $4.5^{\circ} \mathrm{C}$ compared to Beni Ezgen ksur, Tafilelt ksur and open sit houses respectively .

The outdoor air temperatures during day Time in Palme trees site were lower by, $2^{\circ} \mathrm{C}$ than the reference weather station, $3^{\circ}$ to $4^{\circ} \mathrm{C}$ than the ones in Beni Ezgen site, and by $5^{\circ}$ to $8^{\circ} \mathrm{C}$ lower than Tafilelt, and the open site houses as shown in figure (11). During night time the outdoor temperatures in Palme trees site were lower by $5^{\circ}$ to $8^{\circ} \mathrm{C}$ than the Beni Ezgen site, and by $10^{\circ} \mathrm{C}$ lower than Tafilelt, and the open site houses as shown in figure (12).

Two other measurements were taken at street level in two different points in Palme trees site, the fist one at the center of the vegetations and the other at the outer limit of the vegetations. From figure (13), at the outer limit of the vegetation, the outdoor air temperature is higher by 2 to $4^{\circ} \mathrm{C}$ than the temperature in the center of the vegetation, due to the density of Palme trees which gives well shaded area. 


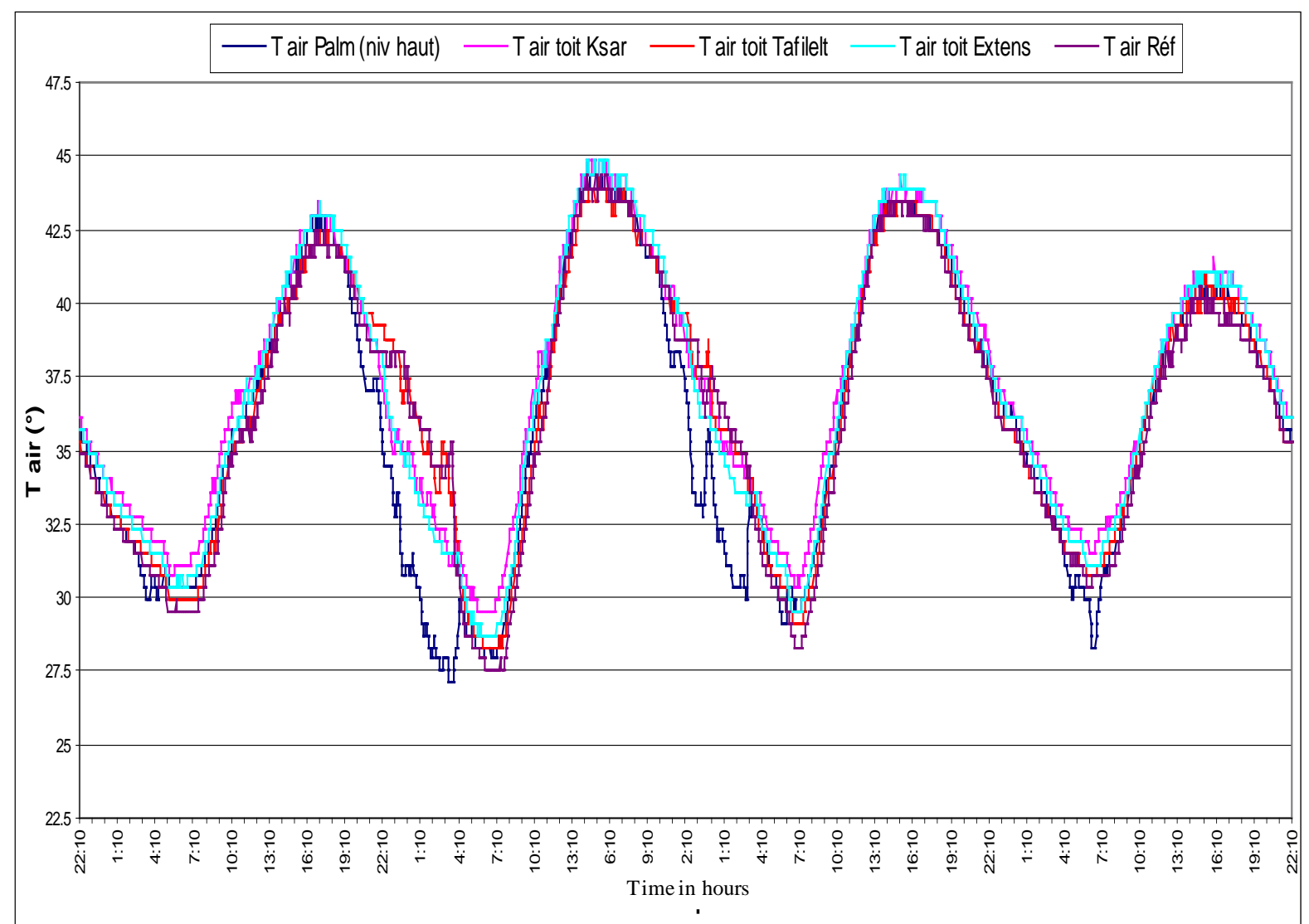

Figure 6. Out door temperature recorded in different zones at canopies level

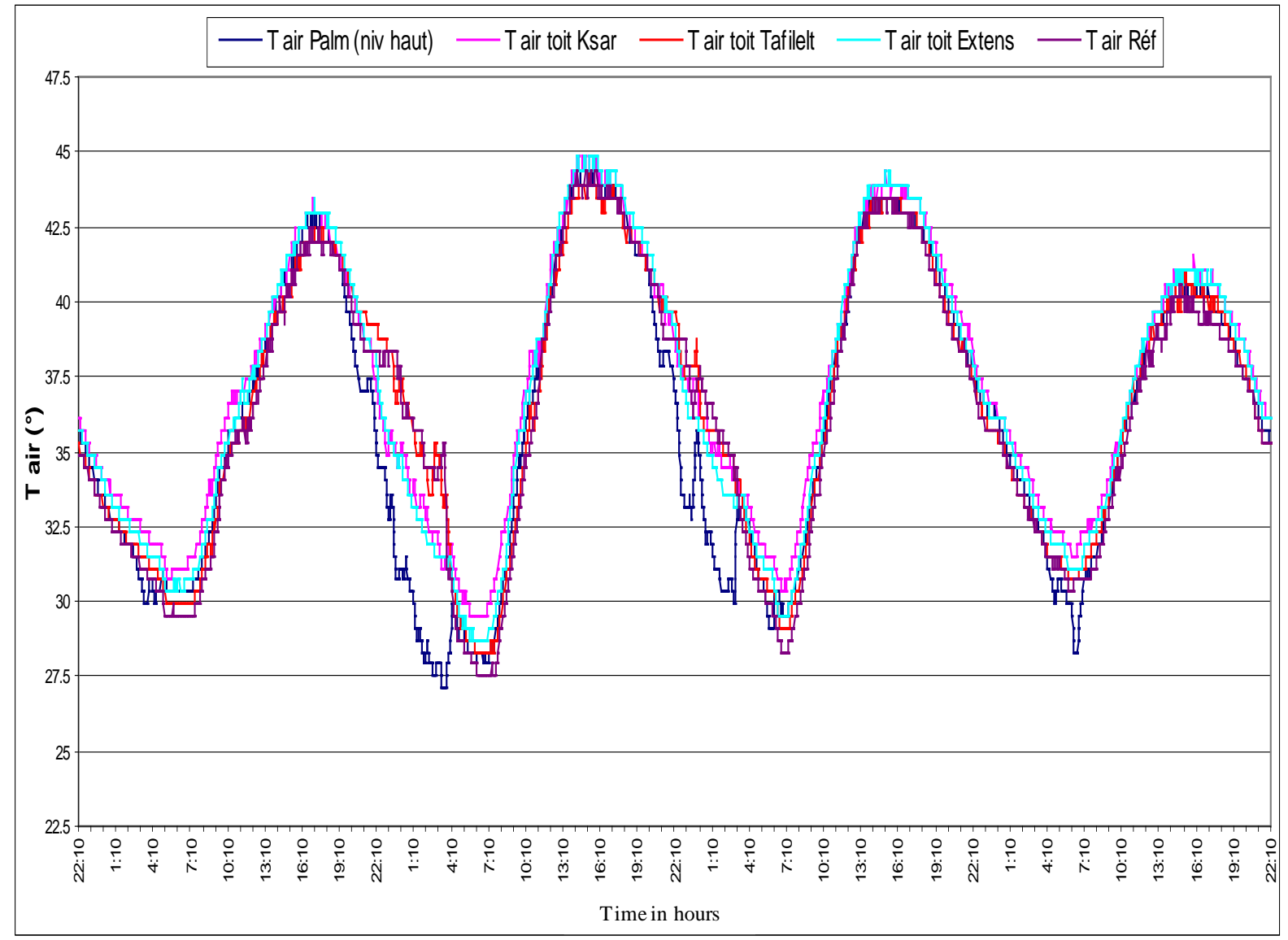

Figure 7. Out door temperature recorded in different zones at street level 


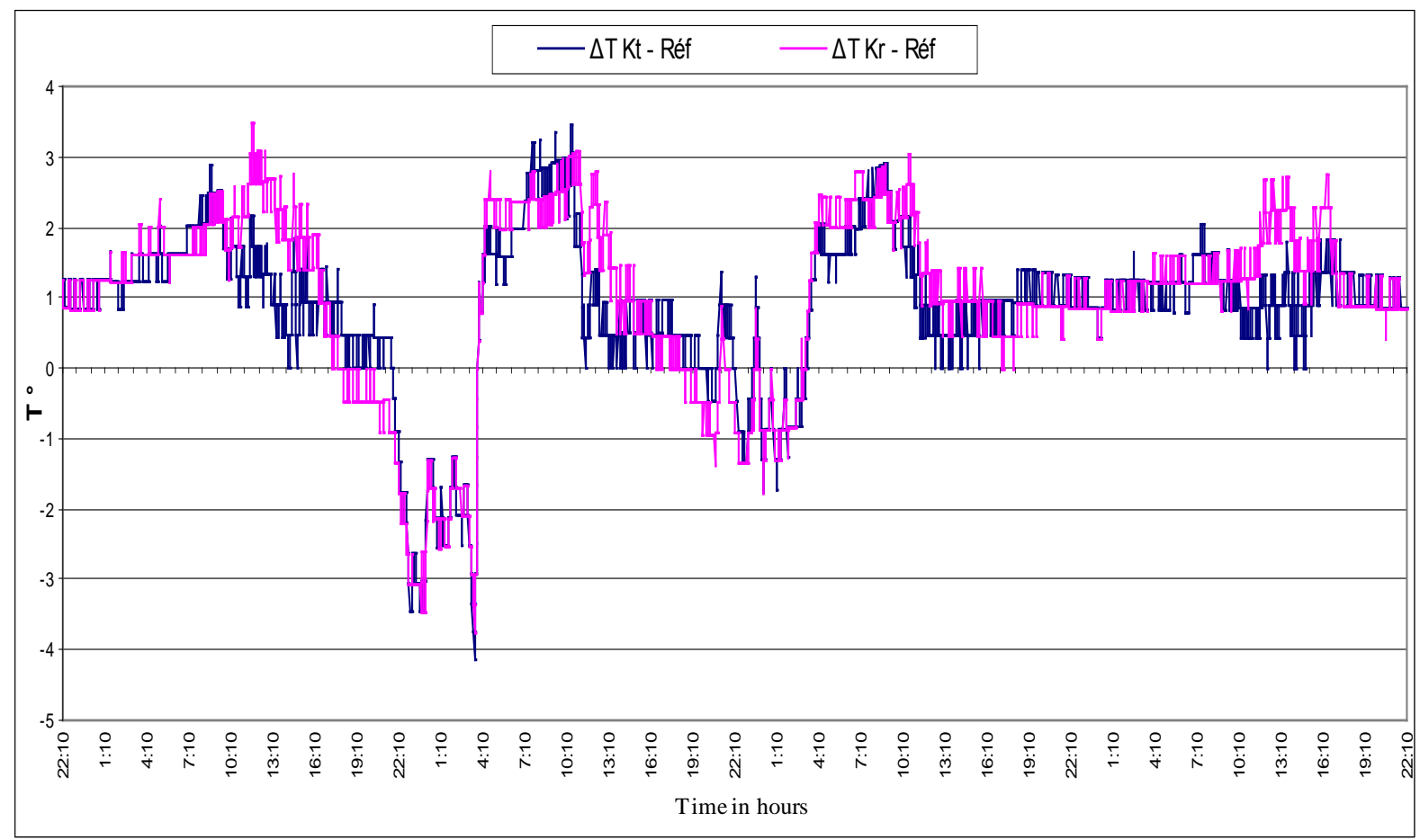

Figure 8. Temperature difference at roof and street level between reference weather station and old ksur

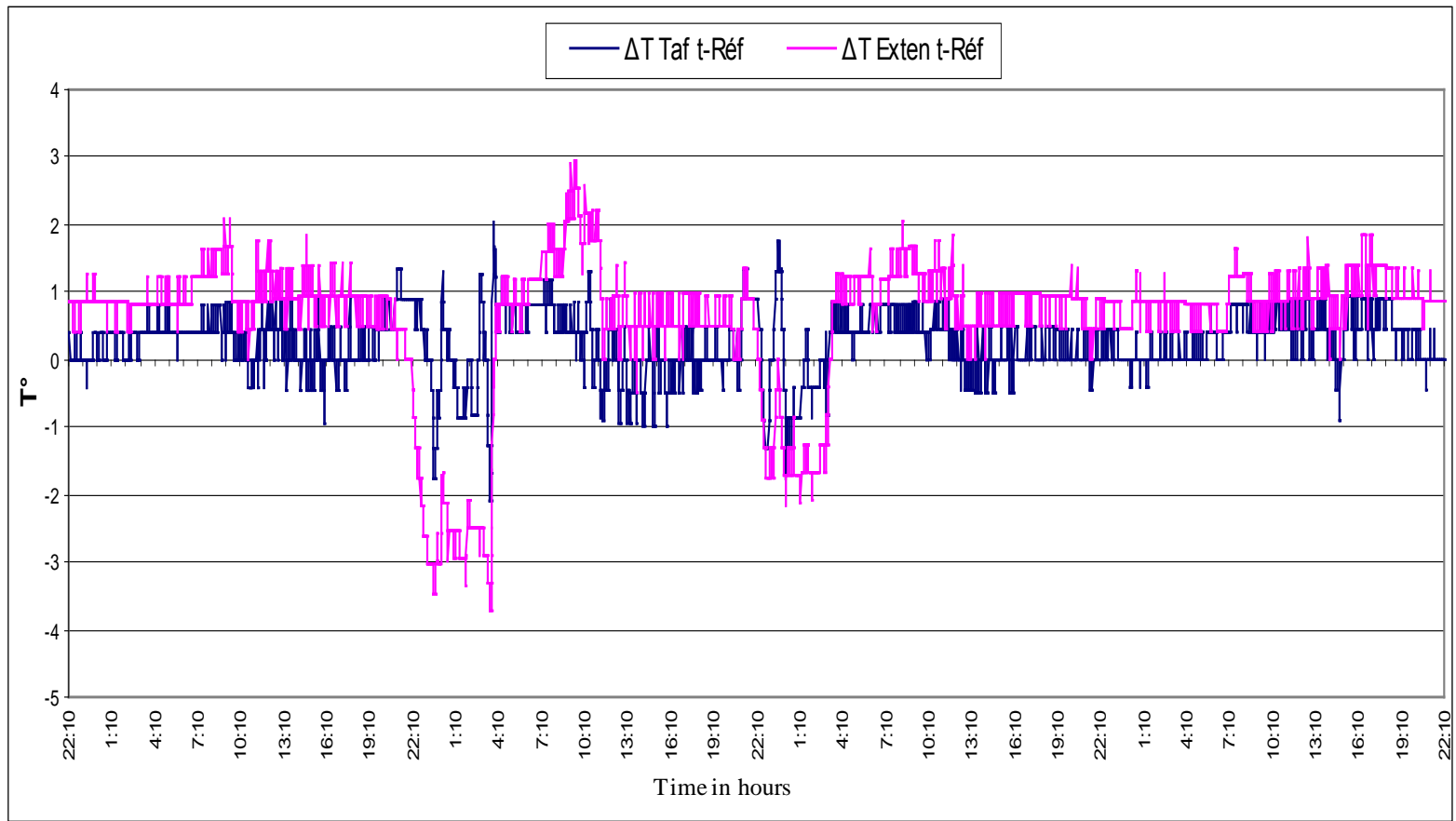

Figure 9. Temperat ure difference at roof 1 level between reference weather station and Tafilelt, and open site 


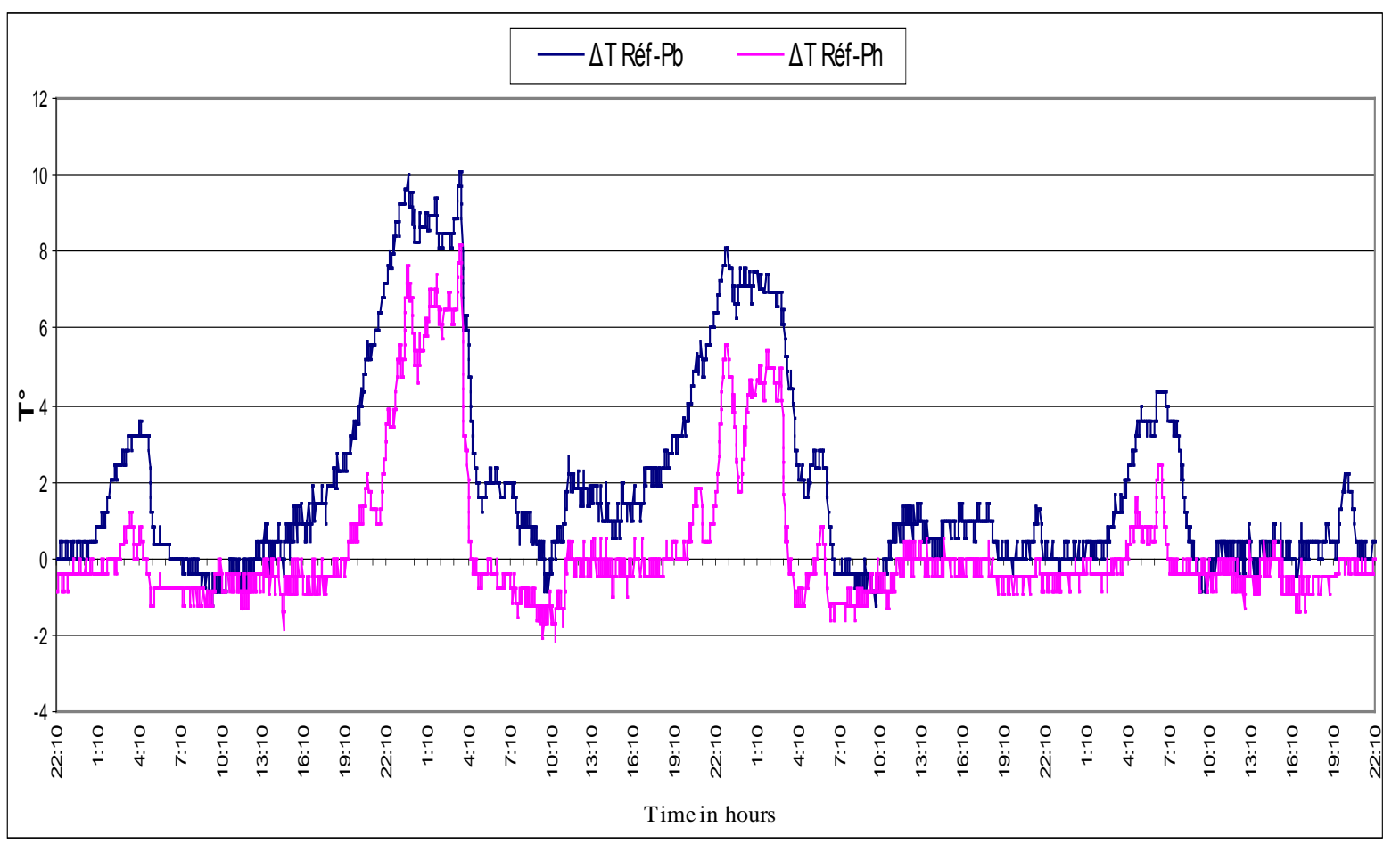

Figure 10. Temperature difference at roof and street level between reference weather station and Palme trees site

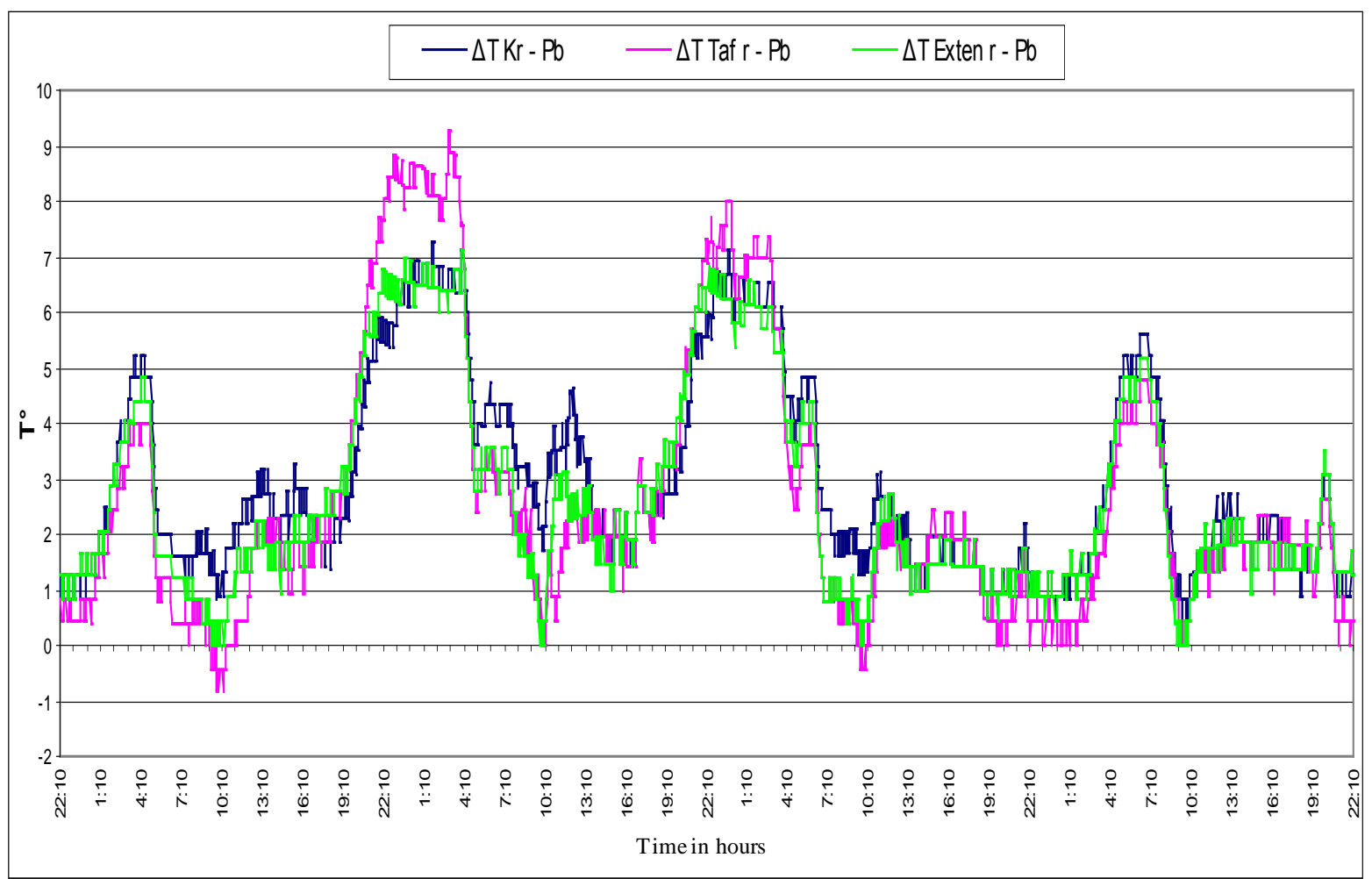

Figure 11. Temperature difference at street level bet ween Palme trees site and old ksur, tafilelt, open site 


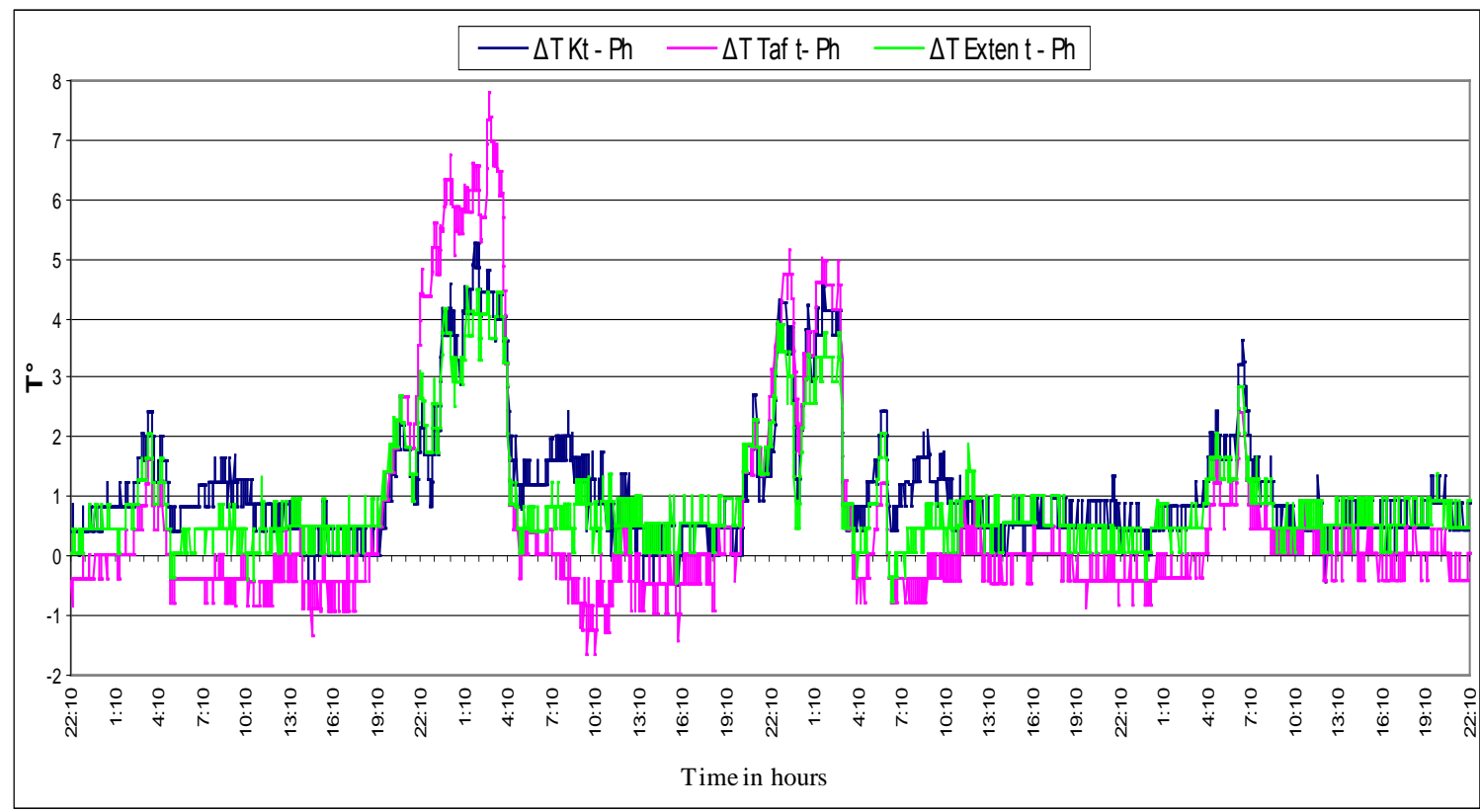

Figure 12. Temperature difference at roof level between Palme trees site and old ksur, tafilelt, open site

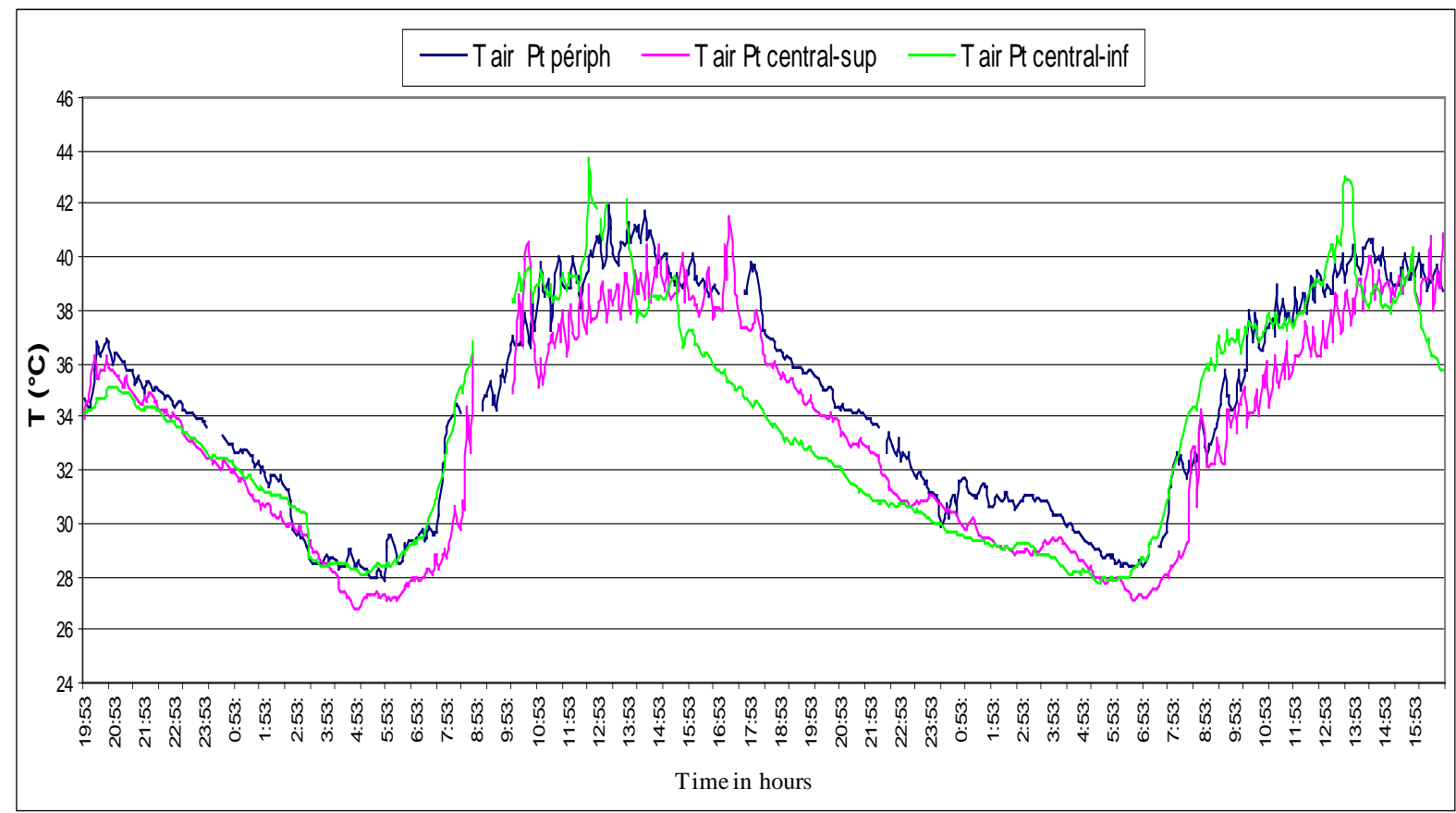

Figure 13. The outdoor air temperat ure at soil level in the middle and extremities of the Palmetrees site

\section{Conclusions}

The study shows that the outdoor temperatures in center of Palme trees site were lower by $5^{\circ}$ to $10^{\circ} \mathrm{C}$ in comparis on to the other studied sites. The old ksur characterized by its compact buildings with narrow streets and its surrounding ramparts was designed to offer a good thermal comfort and security from enemies, however in our days the security problems does not exist. A second ksur called tafilelt was designed in 1990 in the same shape as the old one but with larger streets, for cars and technique equipments to get inside, but our study shows that the outdoor temperatures in the ksur of tafilelt were greater than the outdoor temperatures in Palme trees site. Therefore we suggest a new urbanization method, which gives the vegetations (Palme trees) great space in all buildings design. For further studies it is recommended to find the optimum vegetation surface percentage in the new extension of Ghardaia city. The existence of Palme trees surrounding houses offer a better microclimate, protection from hot wind, sand and also Palme trees fruits (dates) for the inhabitants. 


\section{REFERENCES}

[1] A. Bouchair, A. Dupagne, Building traditions of Mzab facing the challenges of re-shaping of its built form and society, Building \& Environment 2003, 38 1345-1364.

[2] R. Giridhagan \& al, Lowering the outdoor temperature in high-rise-density residential developments of costal Hong Kong: The vegetation influence, Building \& Environment, 2008, 43 1583-1595.

[3] B. Givoni, Climate considerations in building and urban design. USA Wiley, 1998

[4] R. Emmanuel, Summertime heat island effects of urban design parameters, PhD thesis, The University of Michigan, 1997.

[5] L. Shashua-Bar \& al, Integrated thermal effects of generic built forms and vegetation on the UCL microclimate, Building \& Environment, 2006, 41 343-354.

[6] YJ. Huang \& al, The potential of vegetation in reducing the cooling loads in residential buildings, Climate and Applied Meteorology, 1987, 26 1103-16.

[7] H. Akbari \& al, Peak power and cooling energy savings of shade trees, Energy and Buildings, 1997, 26 139-148.
[8] L. Shashua-Bar, ME. Hoffman, Geometry and orientations aspects in passive cooling of cany on streets with trees, Energy and Buildings, 2003, 35 61-68.

[9] M. Santamouris, editer, Energy and Climate in the urban built environment, UK, James \& James, 2001 (chapters 1, 3-7,10,11).

[10] L. Shashua-Bar, ME. Hoffman, Vegetation as climatic component in the design of an urban street, Energy and Buildings, 2000, 31 221-235.

[11] L. Bacci and all, Thermo-hygrometric conditions of some urban parks of Florence, Italy and their effects on human well-being, Proceedings 5th international conference on urban climate, 2003 1-5 September, Lodz, Poland.

[12] R. A. Spronken-Smith and T. R. Oke, The thermal regime of urban parks in two cities with different summer climates, International Journal of Remote Sensing, 1998, 19 2085-104.

[13] E. Correa and al, Impact of urban parks on the climatic pattern of Mendoza's metropolitan area, in Argentina, the 23th conference on passive and low energy architecture, PLEA Geneva Switzerland, 2006 b.

[14] H. Upmanis and al. The influence of green areas on nocturnal temperatures in high city (Goteborg, Sweden), International Journal of climatology, 1198, 18 681-700. 